\title{
Defective Removal of Cellular Cholesterol and Phospholipids by Apolipoprotein A-I in Tangier Disease
}

Gordon A. Francis, Robert H. Knopp, and John F. Oram

Department of Medicine, University of Washington, Seattle, Washington 98195

\begin{abstract}
Tangier disease is a rare genetic disorder characterized by extremely low plasma levels of HDL and apo A-I, deposition of cholesteryl esters in tissues, and a high prevalence of cardiovascular disease. We examined the possibility that HDL apolipoprotein-mediated removal of cellular lipids may be defective in Tangier disease. With fibroblasts from normal subjects, purified apo A-I cleared cells of cholesteryl esters, depleted cellular free cholesterol pools available for esterification, and stimulated efflux of radiolabeled cholesterol, phosphatidylcholine, and sphingomyelin. With fibroblasts from two unrelated Tangier patients, however, apo A-I had little or no effect on any of these lipid transport processes. Intact HDL also was unable to clear cholesteryl esters from Tangier cells even though it promoted radiolabeled cholesterol efflux to levels 50-70\% normal. Passive desorption of radiolabeled cholesterol or phospholipids into medium containing albumin or trypsinized HDL was normal for Tangier cells. Binding studies showed that the interaction of apo A-I with high-affinity binding sites on Tangier fibroblasts was abnormal. These results indicate that apo A-I has an impaired ability to remove cholesterol and phospholipid from Tangier fibroblasts, possibly because of a defective interaction of apo A-I with cell-surface binding sites. Failure of apo A-I to acquire cellular lipids may account for the rapid catabolism of nascent HDL particles and the low plasma HDL levels in Tangier disease. (J. Clin. Invest. 1995. 96:78-87.) Key words: Tangier disease • cellular lipid efflux • high density lipoprotein - apolipoprotein A-I • cardiovascular disease
\end{abstract}

\section{Introduction}

Tangier disease is a rare genetic form of HDL deficiency characterized by extremely low levels of plasma HDL cholesterol and apo A-I (1-3). Patients accumulate massive amounts of cholesteryl esters within macrophages of various tissues, including the tonsils, lymph nodes, liver, spleen, intestinal mucosa,

Address correspondence to John F. Oram, Department of Medicine, RG-26, University of Washington, Seattle, WA 98195. Phone: 206-5433470; FAX: 206-685-3781. Gordon A. Francis' current address is Lipid and Lipoprotein Research Group, 328 HMRC, University of Alberta, Edmonton, Alberta, T6G 2S2, Canada.

Received for publication 13 January 1995 and accepted in revised form 4 April 1995.

J. Clin. Invest.

(c) The American Society for Clinical Investigation, Inc. 0021-9738/95/07/0078/10 \$2.00

Volume 96 , July $1995,78-87$ and in neuronal Schwann cells $(1-3)$. The most prominent clinical features include orange tonsils, hepatosplenomegaly, and peripheral neuropathy. Just under half of the known homozygotes between the ages of 35 and 65 have been reported to have symptoms of cardiovascular disease (4).

The metabolic defect in Tangier disease is unknown. The low plasma HDL levels are caused by a rapid clearance of apo A-I and HDL particles, which is unrelated to a structural defect in apo A-I $(3,5-8)$. Studies by Schmitz and colleagues (911) have suggested that Tangier disease is a disorder of cellular lipid and lipoprotein metabolism. They reported that mononuclear phagocytes from Tangier patients degraded HDL to a greater extent than cells from normal subjects (9) and exhibited abnormalities of phospholipid and cholesterol metabolism (10). They also reported that monocyte-derived macrophages and fibroblasts from Tangier patients had abnormally hyperplastic Golgi complexes (11). Walter et al. (12) recently reported that HDL and apo A-I-containing phospholipid vesicles had abnormal abilities to promote efflux of newly synthesized sterols from Tangier fibroblasts.

One possible explanation for the clinical and biochemical features of Tangier disease is that nascent apo A-I-containing particles are unable to remove excess cholesterol from cells, leading to a massive deposition of sterol in macrophage-containing tissues. Because these nascent particles would not mature to lipid-rich HDL particles, they may be rapidly cleared from the plasma (13). Since HDL apolipoproteins appear to remove cholesterol from fibroblasts and macrophages by similar mechanisms $(11,12,14-17)$, we tested the possibility that a defect in this cholesterol removal process may be expressed in cultured fibroblasts from patients with Tangier disease. Results showed that HDL and apo A-I had virtually no ability to stimulate clearance of cholesteryl esters from sterol-laden Tangier fibroblasts, that apo A-I was ineffective in stimulating cholesterol and phospholipid efflux from these cells, and that highaffinity binding of apo A-I to the surface of Tangier fibroblasts was impaired. Thus the major clinical features of Tangier disease may reflect a cellular defect that leads to an abnormal interaction of HDL apolipoproteins with cell-surface binding sites and impaired removal of cellular phospholipid and cholesterol.

\section{Methods}

Lipoproteins and apolipoproteins. $\mathrm{LDL}$ and $\mathrm{HDL}_{3}$ (hereafter referred to as HDL) were prepared by sequential ultracentrifugation in the density intervals $1.019-1.063$ and $1.125-1.21 \mathrm{~g} / \mathrm{ml}$, respectively. Apo A-I was purified from HDL as previously described (15) and was iodinated by the iodine monochloride method described by Bilheimer (18). LDL was radiolabeled with $\left[{ }^{3} \mathrm{H}\right]$ cholesteryl lineolate as described (19). Trypsinized HDL was prepared as previously described (16) by treating HDL with trypsin for $30 \mathrm{~min}$ at $37^{\circ} \mathrm{C}$ at an HDL:trypsin protein ratio of 40:1. 
Cell lines. Human skin fibroblasts were explanted from two unrelated Tangier patients (TG1 and TG2) and six unrelated normal subjects (NL1-NL6) and were cultured and maintained as previously described (15-17). Cell line TG1 was obtained from a 53-yr-old female previously reported to have extremely low plasma HDL cholesterol and apo A-I levels and clinical symptoms typical of Tangier disease (20). She had a myocardial infarction at age 46 . Fibroblast line TG2 (a generous gift from P.H. Pritchard; University of British Columbia, Vancouver, Canada) was obtained from a 56-yr-old male with clinical; morphological, and biochemical features of Tangier disease, including very low levels of plasma HDL cholesterol and apo A-I (21). This patient died at age 62 of liver failure secondary to B cell lymphoblastic lymphoma and showed no evidence of atherosclerosis on autopsy (4).

Cell culture. Fibroblasts were seeded in 16-mm wells or $35-\mathrm{mm}$ dishes and grown to confluence before experimental use. For most experiments, cells were simultaneously growth-arrested and cholesterolloaded to maximize apolipoprotein-mediated lipid efflux. This was achieved by incubating confluent cells for $48 \mathrm{~h}$ with serum-free DME containing $0.2 \%$ BSA and $30 \mu \mathrm{g} / \mathrm{ml}$ cholesterol. Cells were then washed twice with PBS containing $0.1 \%$ BSA and incubated overnight (16-18 h) in DME/BSA to allow for equilibration of cellular cholesterol pools. In some cases, cholesteryl ester formation was blocked by including an inhibitor of acyl CoA:cholesterol acyltransferase (ACAT), ${ }^{1}$ compound 58.035 ( $2 \mu \mathrm{g} / \mathrm{ml}$; Sandoz AG, Baoel, Switzerland), in the cholesterolloading and equilibration incubation media. Cells were washed once with PBS/BSA before addition of efflux media.

Cellular cholesterol was radiolabeled by three different methods. To introduce a relatively high fraction of label into intracellular compartments, $0.2 \mu \mathrm{Ci}\left[{ }^{3} \mathrm{H}\right.$ ]cholesterol $(40-60 \mathrm{Ci} / \mathrm{mmol}$; Amersham Corp., Arlington Heights, IL) was added to the serum-containing growth medium when cells were $60-80 \%$ confluent. After $3 \mathrm{~d}$, cells were washed twice with PBS/BSA and growth arrested and loaded with nonradioactive cholesterol as described above. Cells were then washed five times with PBS/BSA before addition of efflux media. To selectively radiolabel the plasma membrane of cholesterol-loaded cells (16), fibroblasts were incubated for $2 \mathrm{~h}$ with DME/BSA containing $0.2 \mu \mathrm{Ci} / \mathrm{ml}\left[{ }^{3} \mathrm{H}\right]-$ cholesterol after the overnight equilibration incubation. Cells were washed five times with PBS/BSA before the efflux incubations. To radiolabel cholesterol in sterol-depleted cells by the lysosomal pathway, fibroblasts were incubated for $48 \mathrm{~h}$ with DME containing $10 \%$ lipoprotein-deficient FBS, washed twice with PBS/BSA, and incubated for $6 \mathrm{~h}$ with DME/BSA containing $40 \mu \mathrm{g} / \mathrm{ml} \mathrm{[}{ }^{3} \mathrm{H}$ ] cholesteryl lineolate-labeled LDL. Cells were washed four times with PBS/BSA before the efflux incubations. To radiolabel phospholipids in cholesterol-loaded cells, 10 $\mu \mathrm{Ci} / \mathrm{ml}\left[{ }^{3} \mathrm{H}\right]$ choline chloride (75-85 Ci/mmol; Amersham Corp.) was added to DME/BSA during the overnight equilibration incubations (17). Cells were washed four times with PBS/BSA and incubated for $1 \mathrm{~h}$ at $37^{\circ} \mathrm{C}$ with DME/BSA before the efflux incubations.

Cholesterol and phospholipid efflux. After the appropriate labeling protocol, cells were incubated at $37^{\circ} \mathrm{C}$ with DME/BSA and the indicated additions. At the indicated times, the efflux media was collected and centrifuged to remove cell debris, and cell layers were rinsed twice with ice-cold PBS/BSA and twice with PBS. Media and cells were stored frozen at $-20^{\circ} \mathrm{C}$ until extraction for lipid and protein contents. Efflux media was either counted directly (for cells labeled with $\left[{ }^{3} \mathrm{H}\right]-$ cholesterol) or extracted by the method of Folch et al. (22). Cholesterollabeled cell layers were extracted with hexane:isopropanol (3:2, vol/ vol) as described (15-17). Cells containing labeled phospholipids were extracted with $1 \mathrm{ml}$ of isopropanol for $1 \mathrm{~h}$ and then with hexaneisopropanol as described above.

Sterol species were separated by thin-layer chromatography on silica gel G plates developed in hexane/diethyl ether/methanol/acetic acid

1. Abbreviation used in this paper: ACAT, acyl CoA:cholesterol acyltransferase.
(120:30:10:1.5, vol/vol/vol/vol). Choline-containing phospholipids were separated by thin-layer chromatography on silica gel $\mathrm{H}$ plates developed in chloroform $/ \mathrm{methanol} /$ water $(65: 35: 4, \mathrm{vol} / \mathrm{vol} / \mathrm{vol})$. Lipid spots were identified by staining with $I_{2}$ vapor and comigration with standards. After allowing $I_{2}$ stain to dissipate, appropriate spots were taken for determination of sterol (15-17) and phospholipid mass (23) and/or scintillation counting.

Cell cholesterol esterification. To assess the relative activity of ACAT after incubation with test media, cells were washed once with PBS and incubated for $1 \mathrm{~h}$ at $37^{\circ} \mathrm{C}$ with DME containing $9 \mu \mathrm{M}\left[{ }^{14} \mathrm{C}\right]-$ oleate (50-60 mCi/mmol; Amersham Corp.) bound to $3 \mu \mathrm{M}$ BSA (15$17,19)$. Cells were chilled on ice and washed twice with PBS/BSA and twice with PBS. Cells were stored frozen at $-20^{\circ} \mathrm{C}$ until extraction for lipid and protein as described above. Cell lipids were separated by thin-layer chromatography as described above to determine cholesteryl ester radioactivity. Incorporation of radiolabel into cholesteryl esters represents cholesterol esterification by ACAT.

Sterol and triglyceride biosynthesis. To measure biosynthesis of sterols and triglycerides from acetate, fibroblasts were incubated for $\mathbf{4 8}$ $\mathrm{h}$ in DME containing 10\% lipoprotein-deficient FBS, washed twice with PBS/BSA, and incubated with DME/BSA containing $10 \mu \mathrm{Ci} / \mathrm{ml}$ $\left[{ }^{14} \mathrm{C}\right]$ acetate $(47 \mathrm{mCi} / \mathrm{mmol}$; Amersham Corp. $)$. After $2 \mathrm{~h}$ at $37^{\circ} \mathrm{C}$, cells were chilled on ice and washed twice with PBS, lipids were extracted and isolated by thin-layer chromatography, and spots corresponding to cholesterol and triglycerides were counted for ${ }^{14} \mathrm{C}$-radioactivity.

Cellular binding of apo A-I. Cholesterol-loaded fibroblasts were incubated either at $37^{\circ} \mathrm{C}$ for $2 \mathrm{~h}$ or at $0^{\circ} \mathrm{C}$ for $3 \mathrm{~h}$ with DME/BSA containing the indicated concentrations of ${ }^{125} \mathrm{I}$-apo A-I and unlabeled apo A-I. Cells were washed five times with ice-cold PBS/BSA and twice with PBS. Cell layers were dissolved in $0.1 \mathrm{~N} \mathrm{NaOH}$, and aliquots were taken for quantitation of radioactivity and protein. To identify cell surface-bound ${ }^{125} \mathrm{I}$-apo A-I, cells were dislodged from the dishes with a rubber policeman after the seventh wash and were pelleted in a microfuge. Cell pellets were solubilized in $100-\mu \mathrm{l}$ buffer containing $50 \mathrm{mM}$ Tris, $10 \%$ glycerol, $5 \% \beta$-mercaptoethanol, $1 \mathrm{mM}$ benzamidine, 0.5 $\mathrm{mM}$ EDTA, and $2 \%$ SDS. Aliquots were assayed for protein content, and equal amounts of cellular protein $(50 \mu \mathrm{g})$ were applied to adjacent lanes of a $15 \%$ polyacrylamide gel. After electrophoresis (24), radiolabeled bands were visualized by autoradiography.

\section{Results}

Promotion of cholesterol efflux and clearance of cholesteryl esters by HDL and apo A-I. We compared HDL and purified apo A-I for their abilities to remove cholesterol from sterolladen fibroblasts obtained from normal subjects and two unrelated patients with Tangier disease. Cellular sterols were first labeled to equilibrium by addition of $\left[{ }^{3} \mathrm{H}\right]$ cholesterol tracer to the growth medium when cells were $60-80 \%$ confluent. After $3 \mathrm{~d}$ of growth, confluent cells were cholesterol loaded by incubation for $48 \mathrm{~h}$ with serum-free medium containing unlabeled cholesterol followed by an overnight equilibration in cholesterol-free medium. By labeling before cholesterol loading, cells incorporate a relatively high percentage of cholesterol tracer into intracellular pools $\left(15-40 \%\right.$ of the total cellular $\left[{ }^{3} \mathrm{H}\right]-$ cholesterol becomes esterified by ACAT, depending on the cell line). Normal and Tangier fibroblasts released 3-4\% of the cellular $\left[{ }^{3} \mathrm{H}\right]$ cholesterol into the medium during subsequent 48 $h$ incubations with medium containing only albumin (Fig. 1). Addition of HDL to the albumin medium increased the fractional efflux of $\left[{ }^{3} \mathrm{H}\right]$ cholesterol from both normal and Tangier fibroblasts, although to a lesser extent with Tangier cells. Addition of apo A-I also promoted efflux of $\left[{ }^{3} \mathrm{H}\right]$ cholesterol from normal fibroblasts, but it had little or no effect on $\left[{ }^{3} \mathrm{H}\right]$ cholesterol efflux from Tangier fibroblasts. 


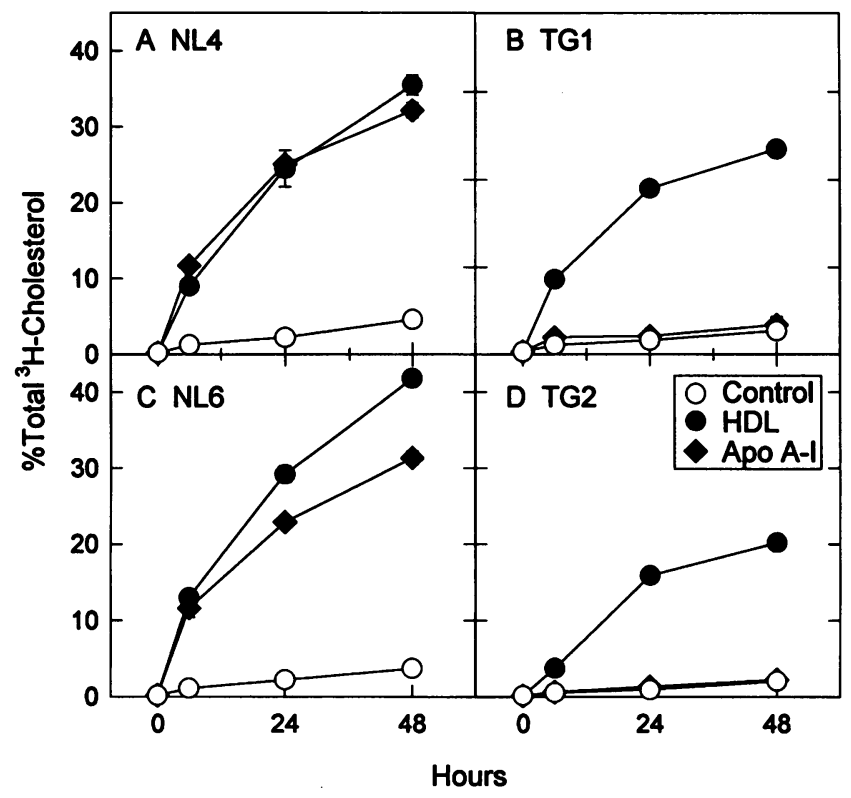

Figure 1. Effects of HDL and apo A-I on $\left[{ }^{3} \mathrm{H}\right]$ cholesterol efflux from cholesterol-loaded normal and Tangier fibroblasts. Two normal ( $N L 4$, $N L 6)$ and two Tangier (TG1, TG2) fibroblast lines were incubated for $72 \mathrm{~h}$ with medium containing $10 \% \mathrm{FBS}$ plus $0.2 \mu \mathrm{Ci} / \mathrm{ml}\left[{ }^{3} \mathrm{H}\right]$ cholesterol to radiolabel cellular pools to equilibrium. Cells were then cholesterolloaded by incubation for $48 \mathrm{~h}$ with serum-free medium containing 2 $\mathrm{mg} / \mathrm{ml}$ albumin plus $30 \mu \mathrm{g} / \mathrm{ml}$ cholesterol. After an overnight equilibration in serum-free medium containing albumin, cells were incubated with medium containing albumin alone ( $O$ ), albumin plus $40 \mu \mathrm{g}$ protein/ $\mathrm{ml} \mathrm{HDL}(\bullet)$, or albumin plus $10 \mu \mathrm{g} / \mathrm{ml}$ apo A-I $(\bullet)$. At the indicated times, dishes were chilled on ice, the medium was removed and assayed for $\left[{ }^{3} \mathrm{H}\right]$ cholesterol, and cells were extracted for measurements of unesterified and esterified cholesterol radioactivity and mass and protein as described in Methods. Results represent the mean \pm SD of triplicate incubations for radiolabel appearing in the medium, expressed as percentage of the total (medium + cell) radioactivity. Mean values for total $\left[{ }^{3} \mathrm{H}\right]-$ cholesterol were $4.7 \times 10^{5}(N L 4), 4.5 \times 10^{5}(N L 6), 4.8 \times 10^{5}(T G 1)$, and $6.0 \times 10^{5}(T G 2) \mathrm{cpm} / \mathrm{mg}$ cell protein. Error bars not shown are within the symbol dimensions.

At the onset of the 48-h incubations, $\sim 20 \%$ of the cellular $\left[{ }^{3} \mathrm{H}\right]$ cholesterol was esterified in normal fibroblast line NL4 and Tangier line TG2, and both cell lines contained similar amounts of cholesteryl esters (Fig. 2). During the 48-h incubations with albumin alone, the cholesterol ester content continued to increase for both cell lines. Addition of either HDL or apo A-I depleted normal cells of cholesteryl esters, with apo A-I being more effective at the concentrations used. HDL and apo A-I also slightly decreased the unesterified $\left[{ }^{3} \mathrm{H}\right]$ cholesterol content of normal fibroblasts. We found similar results with normal fibroblast line NL6 (data not shown). With Tangier fibroblast lines TG2 (Fig. 2) and TG1 (not shown), neither HDL nor apo A-I had a significant effect on the cellular content of cholesteryl ester radiolabel or mass, and only HDL decreased the unesterified $\left[{ }^{3} \mathrm{H}\right]$ cholesterol content. These results show that the ability of apo A-I to deplete cells of cholesteryl esters and to remove unesterified cholesterol is impaired in Tangier fibroblasts. The ability of HDL to deplete cholesteryl esters in Tangier cells was also impaired, although HDL could promote efflux of unesterified $\left[{ }^{3} \mathrm{H}\right]$ cholesterol from these cells (Figs. 1 and 2).

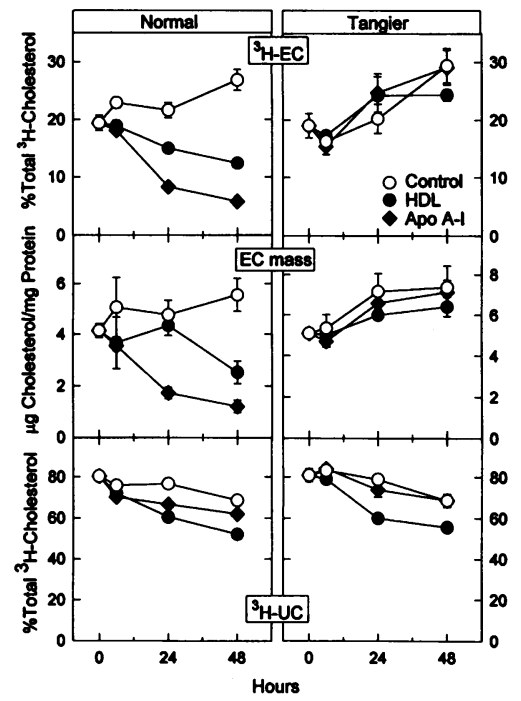

Figure 2. Effect of HDL and apo A-I on unesterified and esterified $\left[{ }^{3} \mathrm{H}\right]-$ cholesterol and esterified cholesterol mass in cholesterol-loaded normal and Tangier fibroblasts. Each value represents the mean \pm SD of triplicate incubations from the same experiment shown in Fig. 1 for normal and Tangier cell lines NL4 and TG2. Values for cellular radiolabeled cholesterol are expressed as percentage of the total radioactivity/dish, and values for cellular cholesterol ester mass are expressed as $\mu \mathrm{g}$ cholesterol/mg cell protein. Error bars not shown are within the symbol dimensions.

Results shown in Figs. 1 and 2 suggest that apo A-I stimulates net turnover of cholesteryl esters in normal cells by removing excess free cholesterol available for reesterification by ACAT, and that this process is defective in Tangier cells. To exclude the possibility of direct modulation of cholesteryl ester hydrolysis, we measured apo A-I-mediated $\left[{ }^{3} \mathrm{H}\right]$ cholesterol efflux from normal (NL4) and Tangier (TG2) fibroblasts when the reesterification branch of the cholesteryl ester cycle was blocked by an ACAT inhibitor (58.035), making cholesteryl ester turnover exclusively dependent on rates of hydrolysis. With the inhibitor present, $50-60 \%$ of the preformed $\left[{ }^{3} \mathrm{H}\right]-$ cholesteryl esters disappeared from both normal and Tangier fibroblasts during 48-h incubations (Fig. 3), indicating that cholesteryl ester hydrolysis was relatively slow in these serumdeprived cells but was similar for the two cell lines. Apo A-I did not directly stimulate cholesteryl ester hydrolysis in either cell line, as it had no effect on cholesteryl ester turnover in the presence of an ACAT inhibitor. In the absence of apo A-I, turnover of $\left[{ }^{3} \mathrm{H}\right]$ cholesteryl esters was associated with an increase in cellular and medium unesterified $\left[{ }^{3} \mathrm{H}\right]$ cholesterol for both cell lines. Exposure of normal cells to apo A-I decreased the cellular content of $\left[{ }^{3} \mathrm{H}\right]$ cholesterol and increased $\left[{ }^{3} \mathrm{H}\right]-$ cholesterol efflux. With Tangier cells, however, apo A-I had no effect on the distribution of $\left[{ }^{3} \mathrm{H}\right]$ cholesterol between cells and medium. We obtained similar results when the same experiment was performed with normal and Tangier cell lines NL6 and TG1 (data not shown). Thus, even when cholesteryl ester turnover was enhanced by blocking reesterification, apo A-I failed to remove cholesterol from Tangier cells.

Cholesterol efflux-stimulating activity of trypsin-labile $H D L$ apolipoproteins. Results from four separate experiments showed that HDL promoted $\left[{ }^{3} \mathrm{H}\right]$ cholesterol efflux from Tangier cells to levels $50-70 \%$ normal, yet HDL had little or no ability to deplete cells of cholesteryl ester (see Fig. 2). This may be because promotion of cholesterol efflux by HDL lipids, which occurs by a desorption/diffusion mechanism (25), is normal in Tangier fibroblasts, while removal of excess cholesterol by HDL apolipoproteins is defective. To further examine 


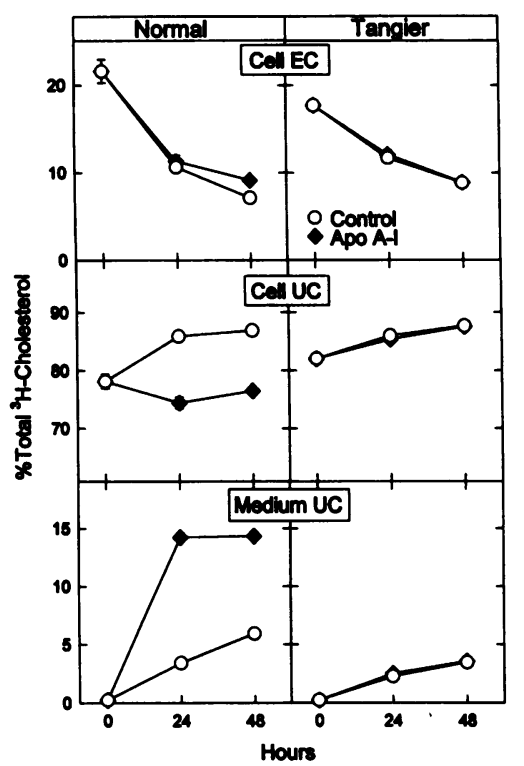
triplicate incubations expressed as percentage of total (medium + cell) radioactivity. Mean values for total $\left[{ }^{3} \mathrm{H}\right]$ cholesterol were $7.8 \times 10^{5}$ $(N L 4)$ and $1.3 \times 10^{6}(T G 2) \mathrm{cpm} / \mathrm{mg}$ cell protein. Error bars not shown are within the symbol dimensions.

this possibility, we measured $\left[{ }^{3} \mathrm{H}\right]$ cholesterol efflux from nor$\mathrm{mal}$ and Tangier cells during 4-h incubations with increasing concentrations of either native HDL or trypsin-treated HDL. Trypsin treatment of HDL abolishes its ability to remove cellular pools of cholesterol accessible to ACAT but has no effect on its ability to stimulate efflux of the bulk of plasma membrane cholesterol (16). For these experiments, we cholesterol loaded prelabeled cells in the presence of an ACAT inhibitor to promote accumulation of unesterified $\left[{ }^{3} \mathrm{H}\right]$ cholesterol within intracellular pools. With normal fibroblasts, trypsin-treated HDL had approximately half the ability of untreated particles to remove $\left[{ }^{3} \mathrm{H}\right]$ cholesterol from cells (Fig. $4 \mathrm{~A}$ ). With Tangier fibroblasts, however, trypsin-treated and untreated HDL had similar abilities to remove $\left[{ }^{3} \mathrm{H}\right]$ cholesterol, and the fractional efflux was similar to that observed for normal cells incubated with trypsinmodified particles (Fig. $4 \mathrm{~B}$ ). Therefore, only the cholesterol efflux component mediated by trypsin-labile HDL apolipoproteins appears to be defective in Tangier cells.

Apo A-I-mediated depletion of cellular cholesterol pools available for esterification. To further test the possibility that removal of excess cholesterol by apo A-I is impaired in Tangier fibroblasts, we compared the ability of apo A-I to deplete normal and Tangier cells of cholesterol that is accessible to esterification by ACAT. We measured both the appearance of $\left[{ }^{3} \mathrm{H}\right]-$ cholesterol in the medium and the subsequent incorporation of $\left[{ }^{14} \mathrm{C}\right]$ oleate into cholesteryl esters on the same dishes after 6and 24-h incubations with different concentrations of apo A-I. With normal cells (NL6), apo A-I increased $\left[{ }^{3} \mathrm{H}\right]$ cholesterol efflux and inhibited cholesterol esterification within $6 \mathrm{~h}$ (Fig. 5). After $24 \mathrm{~h},>85 \%$ of the ACAT-accessible cholesterol was depleted from normal fibroblasts. These effects of apo A-I were relatively high-affinity, in that they saturated at concentrations $<5 \mu \mathrm{g}$ apo A-I/ml $\left(10^{-7} \mathrm{M}\right)$. With Tangier cells (TG1), apo A-I had little or no ability to promote $\left[{ }^{3} \mathrm{H}\right]$ cholesterol efflux

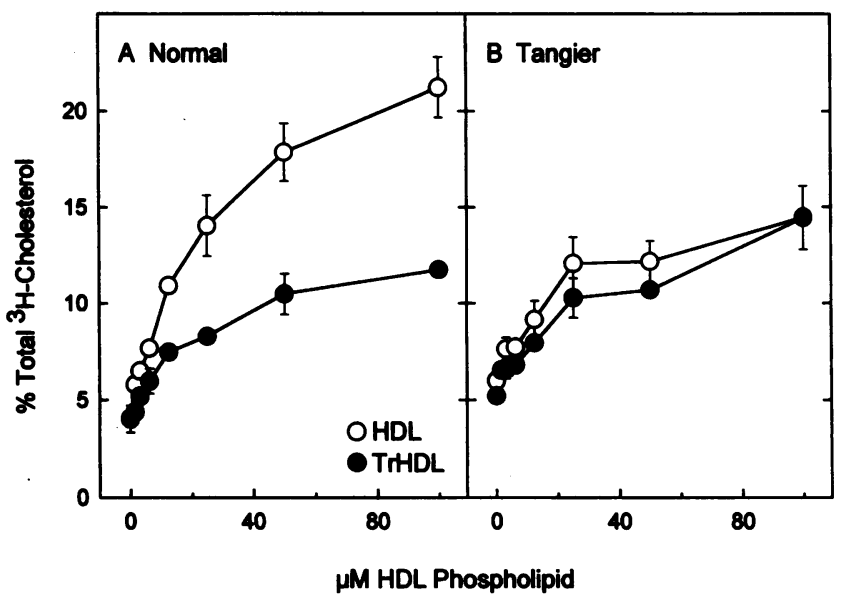

Figure 4. Effect of HDL and trypsin-treated HDL on $\left[{ }^{3} \mathrm{H}\right]$ cholesterol efflux from cholesterol-loaded normal and Tangier fibroblasts. Normal and Tangier fibroblast lines NL6 and TG1 were radiolabeled with $\left[{ }^{3} \mathrm{H}\right]-$ cholesterol and cholesterol loaded as described for Fig. 1, except that ACAT inhibitor $58.035(2 \mu \mathrm{g} / \mathrm{ml})$ was added to the cholesterol loading and equilibration media. Cells were then incubated with medium containing albumin, 58.035, and the indicated concentration of either HDL (O) or trypsin-treated HDL $(T r H D L, \bullet)$. After $4 \mathrm{~h}$, radioactivity in the medium and cells was measured as described in Fig. 1. Values are the mean of duplicate incubations for radioactivity appearing in the medium expressed as percent total radioactivity. Mean values for total $\left[{ }^{3} \mathrm{H}\right]$ cholesterol were $8.1 \times 10^{5}(N L 6)$ and $8.6 \times 10^{5}(T G 1) \mathrm{cpm} / \mathrm{mg}$ cell protein.

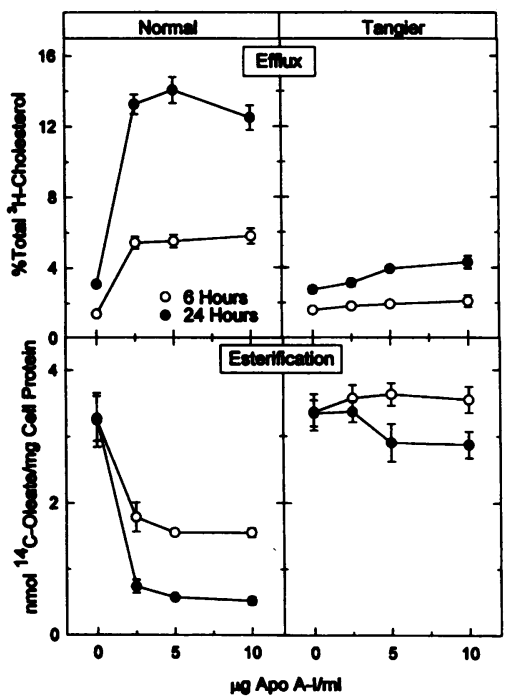

Figure 5. Comparison of apo A-I-mediated cholesterol efflux from normal and Tangier fibroblasts with changes in cellular cholesterol esterification. Normal (NL6) and Tangier (TGl) fibroblasts were radiolabeled with $\left[{ }^{3} \mathrm{H}\right]$ cholesterol and cholesterol loaded as described for Fig. 1. Cells were then incubated with medium containing albumin ( 1 $\mathrm{mg} / \mathrm{ml}$ ) plus the indicated concentrations of apo A-I. After $6 \mathrm{~h}(\mathrm{O})$ or $24 \mathrm{~h}(\bullet)$, the medium was collected, cells were washed and incubated for $1 \mathrm{~h}$ with medium containing $\left[{ }^{14} \mathrm{C}\right]$ oleic acid, and medium radioactivity and cellular $\left[{ }^{3} \mathrm{H}\right]$ cholesterol, $\left[{ }^{3} \mathrm{H}\right]$ cholesteryl ester, and cholesteryl $\left[{ }^{14} \mathrm{C}\right]$ oleate was measured as described in Methods. Efflux represents the percent of total ${ }^{3} \mathrm{H}$ radioactivity appearing in the medium, while esterification represents nanomole $\left[{ }^{14} \mathrm{C}\right.$ ] oleate incorporated into cellular cholesterol esters/mg cell protein. Each value is the mean \pm SD of triplicate incubations. Mean values for total $\left[{ }^{3} \mathrm{H}\right]$ cholesterol were $6.9 \times 10^{5}$ (NL6) and $7.1 \times 10^{5}(T G 1) \mathrm{cpm} / \mathrm{mg}$ cell protein. 


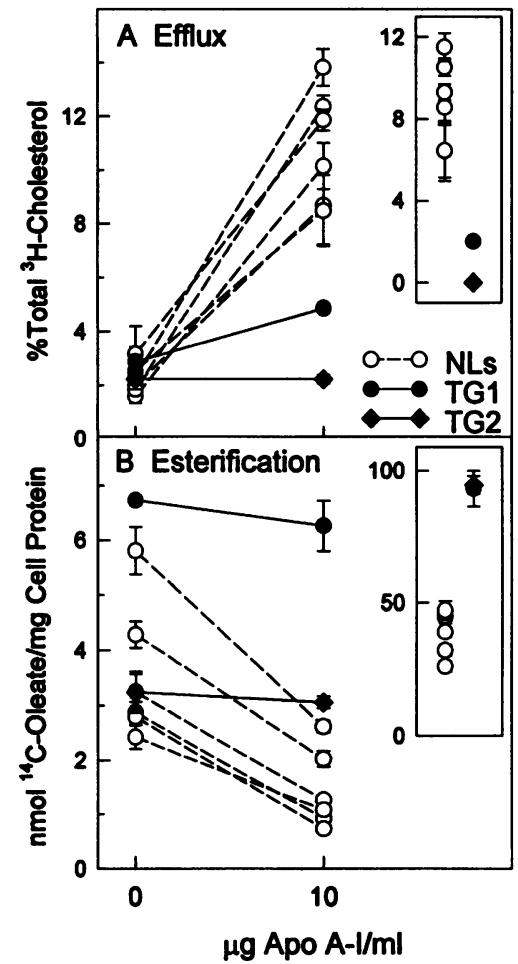

Figure 6. Cell-line comparisons of apo A-I-mediated $\left[{ }^{3} \mathrm{H}\right]$ cholesterol efflux and inhibition of cellular cholesterol esterification. Six normal $(N L 1-N L 6)$ and two Tangier (TG1 and TG2) fibroblast lines were treated as described for Fig. 5, except that the efflux incubations were for $6 \mathrm{~h}$ with the indicated concentrations of apo A-I. Each value is the mean $\pm S D$ for triplicate incubations expressed as percent total $\left[{ }^{3} \mathrm{H}\right]$ cholesterol (medium + cell).

Mean values for total $\left[{ }^{3} \mathrm{H}\right]$ cholesterol were 3.9 $\times 10^{5}(N L 1), 4.3 \times 10^{5}$ (NL2), $4.4 \times 10^{5}(N L 3)$, $4.9 \times 10^{5}(N L 4), 6.1$ $\times 10^{5}(N L 5), 5.5 \times 10^{5}$ $(N L 6), 6.9 \times 10^{5}$ (TGI), and $6.2 \times 10^{5}$ (TG2) $\mathrm{cpm} / \mathrm{mg}$ cell protein. Values in the inset for Panel $A$ represent apo A-I-mediated $\left[{ }^{3} \mathbf{H}\right]$ cholesterol efflux, calculated as the difference between efflux in the presence of apo A-I and the mean efflux in the absence of apo A-I. The inset for panel $B$ is the fractional apo A-I-mediated inhibition of cholesterol esterification (esterification in the presence of apo A-I as a percentage of the mean esterification with apo A-I absent).

and inhibit cholesterol esterification, indicating that apo A-I was unable to effectively remove ACAT-accessible cholesterol from these cells.

We compared the two Tangier cell lines with six normal cell lines for changes in $\left[{ }^{3} \mathrm{H}\right]$ cholesterol efflux and cholesterol esterification after exposure to apo A-I. In the presence of albumin alone, $\left[{ }^{3} \mathrm{H}\right]$ cholesterol efflux from both Tangier lines was within the range observed for normal cells (Fig. $6 \mathrm{~A}$ ). Addition of $10 \mu \mathrm{g} / \mathrm{ml}$ apo A-I increased [ ${ }^{3} \mathrm{H}$ ] cholesterol efflux severalfold from all six normal cell lines, while it had either no effect (TG2) or caused only a small increase (TG1) from the Tangier cell lines. Thus, apo A-I-mediated $\left[{ }^{3} \mathrm{H}\right]$ cholesterol efflux from both Tangier cell lines was markedly below normal (Fig. 6 $A$, inset). In the presence of albumin alone, incorporation of $\left[{ }^{14} \mathrm{C}\right]$ oleate into cholesteryl esters varied threefold among the eight different cell lines (Fig. 6 B). Although TG1 had a higher than normal esterification rate in this experiment, values for TG2 fell within the normal range. Addition of apo A-I inhibited cholesterol esterification for all normal lines, with fractional inhibitions ranging from 50-75\% (Fig. $6 \mathrm{~B}$, inset). In contrast, despite twofold differences in baseline values, both TG1 and TG2 showed little change in cholesterol esterification when exposed to apo A-I. These multiple cell line comparisons indicate that removal of ACAT-accessible cholesterol by apo A-I is defective in both of these Tangier cell lines.

Apo A-I-mediated efflux of LDL-derived and plasma membrane cholesterol. We also measured the ability of apo A-I to promote $\left[{ }^{3} \mathrm{H}\right]$ cholesterol efflux from normal and Tangier

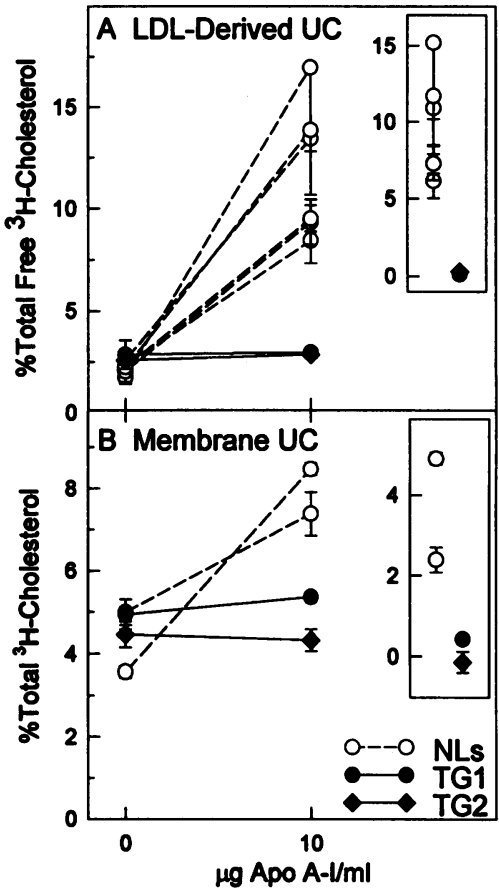

Figure 7. Cell-line comparisons of apo A-I-mediated efflux of $\left[{ }^{3} \mathrm{H}\right]$ cholesterol derived from LDL or the plasma membrane. For panel $A$, six normal and two Tangier fibroblast lines were incubated for $48 \mathrm{~h}$ with lipoprotein-deficient serum to up-regulate $\mathrm{LDL}$ receptors and then were incubated with serumfree medium containing albumin plus $40 \mu \mathrm{g}$ protein/ml LDL radiolabeled with $\left[{ }^{3} \mathrm{H}\right]$ cholesteryl linoleate. After $6 \mathrm{~h}$ cells were washed and incubated with albumin medium containing the indicated concentration of apo A-I for $18 \mathrm{~h}$, and medium and cellular $\left[{ }^{3} \mathrm{H}\right]$ cholesterol and cellular $\left[{ }^{3} \mathrm{H}\right]$ cholesteryl esters were measured. Results are the mean $\pm S D$ of triplicate incubations expressed as percent of total free $\left[{ }^{3} \mathrm{H}\right]$ cholesterol appearing in the medium. Results were similar when values were calculated as percentage of total (free plus esterified) $\left[{ }^{3} \mathrm{H}\right]$ cholesterol. Mean total free $\left[{ }^{3} \mathrm{H}\right]$ cholesterol were $1.5 \times 10^{4}(N L 1), 8.8 \times 10^{3}(N L 2), 8.9 \times 10^{3}(N L 3)$, $1.7 \times 10^{4}(N L A), 1.5 \times 10^{4}(N L 5), 1.3 \times 10^{4}(N L 6), 1.1 \times 10^{4}(T G 1)$, and $1.3 \times 10^{4}(T G 2) \mathrm{cpm} / \mathrm{mg}$ cell protein. For panel $B$, normal $(N L 2$, NL6) and Tangier fibroblasts were cholesterol-loaded as described for Fig. 1 and radiolabeled by incubating cells for $2 \mathrm{~h}$ with albumin medium containing $\left[{ }^{3} \mathrm{H}\right.$ ] cholesterol tracer immediately preceding the efflux incubations. After an additional $4 \mathrm{~h}$ incubation with albumin medium \pm apo A-I, medium and cellular $\left[{ }^{3} \mathrm{H}\right]$ cholesterol was measured. Each value is the mean $\pm S D$ of triplicate incubations expressed as percent total $\left[{ }^{3} \mathrm{H}\right]$ cholesterol appearing in the medium. Mean total $\left[{ }^{3} \mathrm{H}\right]$ cholesterol were $6.4 \times 10^{5}(N L 2), 1.4 \times 10^{6}(N L 6), 1.1 \times 10^{6}(T G 1)$, and $9.9 \times 10^{5}$ (TG2) $\mathrm{cpm} / \mathrm{mg}$ cell protein. Insets represent apo A-I-mediated $\left[{ }^{3} \mathrm{H}\right]-$ cholesterol efflux calculated as described for Fig. 6 A.

fibroblasts that were prelabeled with $\left[{ }^{3} \mathrm{H}\right]$ cholesterol by two additional methods. First, we incubated cells grown in the presence of lipoprotein-deficient serum with $\left[{ }^{3} \mathrm{H}\right]$ cholesteryl linoleate-labeled LDL and measured the appearance of $\left[{ }^{3} \mathrm{H}\right]-$ cholesterol in the medium during subsequent 18 -h incubations (Fig. $7 \mathrm{~A}$ ). This method radiolabels cells with $\left[{ }^{3} \mathrm{H}\right]$ cholesterol liberated from lysosomal hydrolysis of LDL sterols internalized by the LDL receptor pathway ( $>80 \%$ of the LDL radiolabel was converted to unesterified $\left[{ }^{3} \mathrm{H}\right]$ cholesterol by all cell lines). Second, we pulse-incubated cells for $2 \mathrm{~h}$ with $\left[{ }^{3} \mathrm{H}\right]$ cholesterol after cholesterol loading and then measured $\left[{ }^{3} \mathrm{H}\right]$ cholesterol efflux during 4-h chase incubations (Fig. $7 \mathrm{~B}$ ). This method selectively labels the plasma membrane $(<2 \%$ of the cellassociated radiolabeled sterol was esterified after the pulse and chase incubations). In the presence of albumin alone, efflux of either LDL-derived or plasma membrane $\left[{ }^{3} \mathrm{H}\right]$ cholesterol from Tangier cells was within the range observed for normal cells. Addition of apo A-I increased LDL-derived and plasma membrane $\left[{ }^{3} \mathrm{H}\right]$ cholesterol efflux from six (Fig. $7 \mathrm{~A}$ ) and two (Fig. $7 B$ ) normal cell lines, respectively. In contrast, apo A-I had 


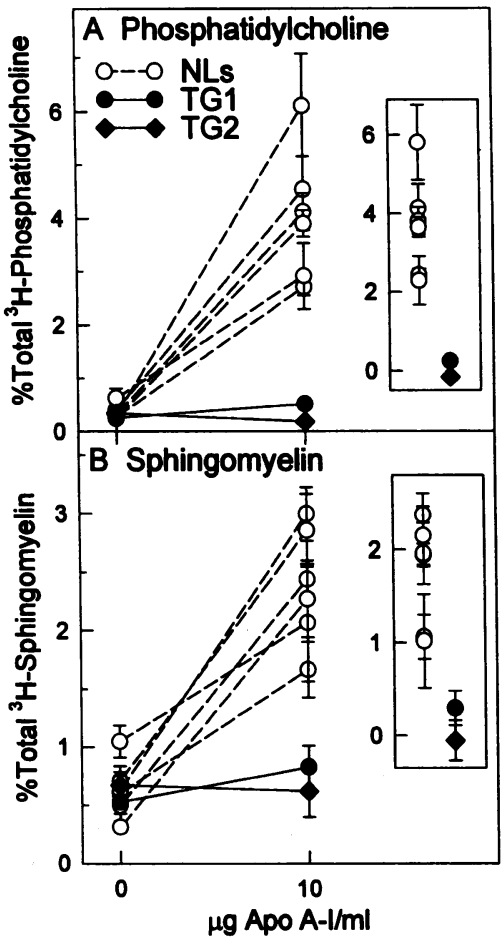

protein are shown in Fig. 9, $F$ and $G$. Inset values represent apo A-Imediated radiolabeled phospholipid efflux calculated as described for Fig. $6 \mathrm{~A}$.

virtually no effect on efflux of both sources of $\left[{ }^{3} \mathrm{H}\right]$ cholesterol from Tangier cells (Fig. 7, insets). Thus, apo A-I-mediated $\left[{ }^{3} \mathrm{H}\right]$ cholesterol efflux was markedly subnormal in both Tangier cell lines when cellular cholesterol was radiolabeled by three independent methods. These results suggest that removal of plasma membrane cholesterol by apo A-I is impaired in Tangier fibroblasts.

Apo A-I-mediated phospholipid efflux. Apo A-I can remove both cholesterol and phospholipids from the plasma membrane of cultured cells $(17,26-29)$. To test the possibility that removal of phospholipid by apo A-I is also defective in Tangier cells, we measured the ability of apo A-I to stimulate efflux of radiolabeled phosphatidylcholine and sphingomyelin after phospholipids in cholesterol-loaded cells were labeled with $\left[{ }^{3} \mathrm{H}\right]$ choline. Efflux of radiolabeled phosphatidylcholine (Fig. $8 A$ ) and sphingomyelin (Fig. $8 B$ ) from two Tangier cell lines was within the range observed for six normal cell lines when only albumin was present in the medium. Addition of apo A-I stimulated efflux of both phospholipid species from all six normal cell lines but had little or no effect on phospholipid efflux from Tangier cells. Therefore, apo A-I-mediated removal of both cholesterol and phospholipid from Tangier cells was markedly reduced or absent when compared to six different normal cell lines.

Cellular lipid parameters among normal and Tangier fibroblast lines. We compared other parameters of cellular lipid metabolism among the different fibroblast cell lines when normalized to cellular protein. Receptor-mediated uptake of LDL cholesterol varied twofold among the six normal and two Tangier lines, but the Tangier cells were within the normal range

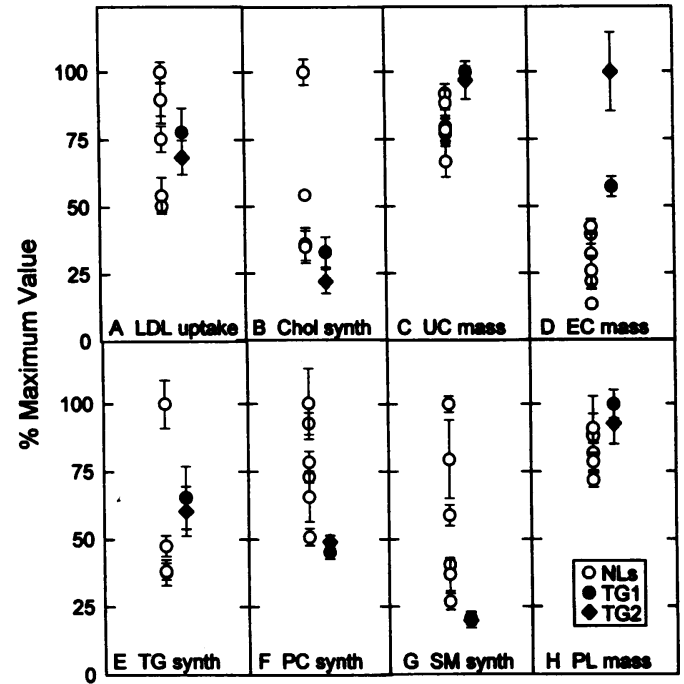

Figure 9. Comparison of different parameters of cellular lipid metabolism among normal and Tangier fibroblast lines. LDL uptake $(A)$ is the total amount of $\left[{ }^{3} \mathrm{H}\right]$ cholesterol-linoleate-labeled LDL associated with cells and resecreted into the chase medium for the experiment described in Fig. $7 A$ (mean \pm SD of six dishes). To measure cholesterol $(B)$ and triglyceride $(E)$ synthesis, four normal $(N L 2, N L 3, N L 5, N L 6)$ and the two Tangier fibroblast lines were incubated in triplicate for $48 \mathrm{~h}$ with lipoprotein-deficient serum and were then chased for $2 \mathrm{~h}$ with $\left[{ }^{14} \mathrm{C}\right]$ acetate. Cellular lipids were extracted for determination of $\left[{ }^{14} \mathrm{C}\right]$ sterols and $\left[{ }^{14} \mathrm{C}\right]$ triglycerides as described in Methods. Values are the mean \pm SD of triplicate dishes. Unesterified $(C)$ and esterified $(D)$ cholesterol mass was measured for all six normal and two Tangier cells after they were grown to confluence in $10 \%$ FBS. Values are the mean \pm SD of quadruplicate dishes. Values for synthesis of phosphatidyl $\left[{ }^{3} \mathrm{H}\right]$ choline $(F)$ and $\left[{ }^{3} \mathrm{H}\right]$ sphingomyelin $(G)$ are from the experiment described in Fig. 8 (mean \pm SD of six dishes). Total phospholipid mass was measured as described in Methods after cells were cholesterol loaded as in Fig. 8 and panels $F$ and $G$. Values are the mean $\pm S D$ of triplicate dishes. All values were normalized for cellular protein and are expressed as the percentage of the mean for the cell line with the maximum value. Mean 100\% values were: $2.36 \mu \mathrm{g}$ LDL cholesterol/ $\mathrm{mg}(A), 5.5 \times 10^{6} \mathrm{cpm} / \mathrm{mg}(B), 54 \mu \mathrm{g} / \mathrm{mg}(C), 3.5 \mu \mathrm{g} / \mathrm{mg}(D), 3.7$ $\times 10^{4} \mathrm{cpm} / \mathrm{mg}(E), 4.7 \times 10^{6} \mathrm{cpm} / \mathrm{mg}(F), 3.3 \times 10^{5} \mathrm{cpm} / \mathrm{mg}(G)$, and $311 \mathrm{nmol}$ phosphorous $/ \mathrm{mg}(H)$.

(Fig. 9 A). After stimulation of sterol synthesis by treatment with lipoprotein-deficient serum, $\left[{ }^{14} \mathrm{C}\right]$ acetate incorporation into sterols varied fourfold among four normal and two Tangier cell lines, with the Tangier cells having the lowest values (Fig. $9 B)$. Under the same conditions, incorporation of $\left[{ }^{14} \mathrm{C}\right]$ acetate into triglycerides by Tangier cells was within the normal range (Fig. $9 E$ ). When cells were grown to confluence without cholesterol loading, the unesterified cholesterol mass was slightly above the range observed for the six normal fibroblast lines (Fig. $9 \mathrm{C}$ ). The esterified cholesterol mass was significantly higher than normal for the two Tangier lines (Fig. $9 D$ ), but the cellular content of cholesterol esters was relatively low with these nonloaded cells, being $<7 \%$ of the total cholesterol. Synthesis of both phosphatidylcholine and sphingomyelin from $\left[{ }^{3} \mathrm{H}\right]$ choline varied two- to fourfold among the eight cell lines, with the two Tangier lines being at the bottom of the normal range (Fig. 9, $F$ and $G$ ). In contrast, the total phospholipid mass varied only modestly among cell lines, with Tangier cells 


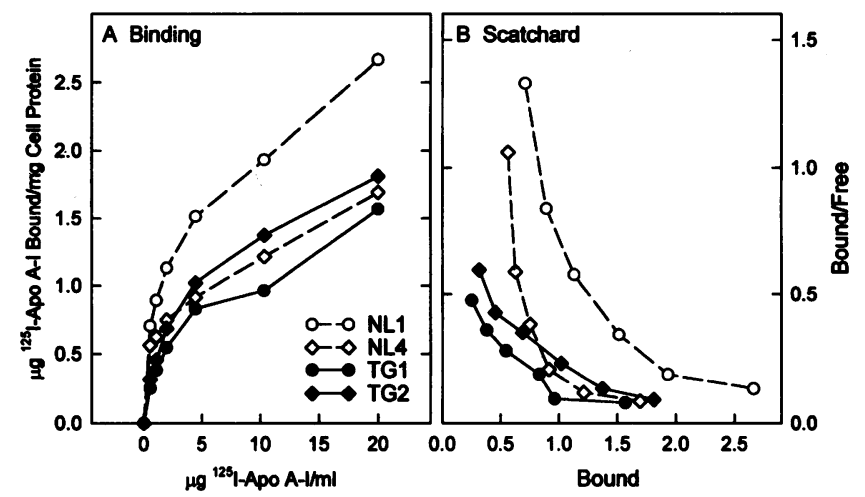

Figure 10. Binding of ${ }^{125} \mathrm{I}$-apo A-I to cholesterol-loaded normal and Tangier fibroblasts. Normal and Tangier fibroblasts were cholesterol loaded as described for Fig. 1, and incubated for $2 \mathrm{~h}$ at $37^{\circ} \mathrm{C}$ with medium containing $1 \mathrm{mg} / \mathrm{ml}$ albumin plus the indicated concentrations of ${ }^{125} \mathrm{I}$-apo A-I. After chilling on ice and washing extensively, cells were solubilized in $0.1 \mathrm{~N} \mathrm{NaOH}$ for radioactivity and protein analysis. Each value in $A$ is cell-associated radioactivity for duplicate incubations expressed as microgram ${ }^{125} \mathrm{I}$-apo A-I equivalents. $B$ is a reciprocal Scatchard plot of the values shown in $A$.

having the highest phospholipid content (Fig. $9 H$ ). Thus Tangier fibroblasts tended to have lower than normal rates of sterol and phospholipid synthesis but slightly higher than normal cholesterol and phospholipid to protein ratios.

Binding of apo A-I to fibroblasts. The inability of apo A-I to effectively remove lipids from the plasma membrane of Tangier fibroblasts raises the possibility that the interaction of apo A-I with cell surface binding sites is defective in these cells. To test this possibility; we incubated two normal and two Tangier fibroblast lines with iodinated apo A-I at $37^{\circ} \mathrm{C}$ and measured cell-associated radioactivity after sequential washing of cells at $0^{\circ} \mathrm{C}$. Concentration curves revealed that ${ }^{125} \mathrm{I}$-apo A-I interacted extensively ( $\sim 10^{7}$ molecules/cell at $20 \mu \mathrm{g} / \mathrm{ml}$ ) with all four cell lines in a partially saturable manner (Fig. $10 \mathrm{~A}$ ). Reciprocal Scatchard plots of the binding data were hyperbolic for all cell lines (Fig. $10 \mathrm{~B}$ ), suggesting that ${ }^{125} \mathrm{I}$-apo A-I remained associated with multiple binding sites after extensive washing of cells. The overall affinity of these binding sites on Tangier cells were apparently below normal, as Scatchard plots for both Tangier cell lines were more linear and had lower slopes than those for the normal cell lines. Thus, Tangier cells appear to have a subnormal ability to bind apo A-I to its highest affinity sites.

To further test for impaired apo A-I binding to Tangier fibroblasts, we compared binding of ${ }^{125}$ I-apo A-I among the two Tangier and six normal fibroblast lines. At a concentration of $0.5 \mu \mathrm{g} / \mathrm{ml}$, high-affinity binding of ${ }^{125} \mathrm{I}$-apo A-I to both Tangier lines was below the normal range when the binding assays were performed at either $4^{\circ} \mathrm{C}$ (Fig. $11 \mathrm{~A}$ ) or $37^{\circ} \mathrm{C}$ (Fig. $11 \mathrm{~B}$ ). Since this difference was observed at $4^{\circ} \mathrm{C}$, it cannot be attributed to reduced internalization or enhanced degradation of cell-associated ${ }^{125} \mathrm{I}$-apo A-I. To insure that the cell-associated radioactivity represented intact ${ }^{125} \mathrm{I}$-apo A-I, we assayed equal amounts of cellular protein by SDS-PAGE after performing the binding assays at $4^{\circ} \mathrm{C}$ with $1 \mu \mathrm{g} / \mathrm{ml}{ }^{125} \mathrm{I}$-apo A-I. Autoradiographs revealed that nearly all the radioactivity was associated with intact apo A-I for all eight cell lines and that the two Tangier lines bound markedly less ${ }^{125} \mathrm{I}$-apo A-I than any of the normal cells (Fig. $11 C$ ). These results demonstrate that, at low concentrations $\left(3 \times 10^{-8} \mathrm{M}\right)$, the interaction of apo A-I with cell surface binding sites is impaired in the two Tangier fibroblast lines.

\section{Discussion}

The current study shows that removal of cellular cholesterol and phospholipids by apo A-I is defective in fibroblasts from two unrelated subjects with Tangier disease. When cholesterolloaded fibroblasts from as many as six normal subjects were exposed to apo A-I, efflux of radiolabeled cholesterol, phosphatidylcholine, and sphingomyelin increased severalfold within 6 h. This was associated with a depletion of ACAT-accessible cholesterol and an increased turnover of preformed cholesteryl esters, indicating that apo A-I cleared excess cholesterol from normal cells. These results are similar to those reported previously showing that purified apo A-I can stimulate transport of cholesterol and phospholipids from fibroblast and macrophages (17, 26-29). In contrast to its effect on normal cells, apo A-I had little or no ability to stimulate cholesterol and phospholipid efflux from Tangier fibroblasts.

Apo A-I had an impaired ability to stimulate cholesterol efflux from Tangier fibroblasts when cellular cholesterol was radiolabeled either from exogenous $\left[{ }^{3} \mathrm{H}\right]$ cholesterol tracer or from lysosomal degradation of $\left[{ }^{3} \mathrm{H}\right]$ cholesteryl lineolate delivered to cells by the LDL receptor pathway. These results suggest that apo A-I is unable to remove cholesterol from the plasma membrane of Tangier fibroblasts. Efflux of radiolabeled cholesterol to albumin or trypsinized HDL appeared to be normal in Tangier fibroblasts, indicating that cholesterol desorption from the plasma membrane was not impaired in these cells. As apo A-I-mediated phospholipid efflux was also markedly subnormal in these cells, the defect in removal of cholesterol by apo A-I may be secondary to a lack of ability of apo A-I to extract plasma membrane phospholipid and form cholesterol acceptor particles. HDL particles, however, were no more effective in clearing cholesteryl esters from Tangier fibroblasts than apo AI, even though HDL contains phospholipids and could promote cholesterol efflux from Tangier cells. Moreover, efflux of radiolabeled phospholipid to albumin was normal in Tangier cells, indicating that plasma membrane phospholipids were accessible for desorption from these cells. These findings suggest that HDL apolipoproteins cannot remove lipid from Tangier fibroblasts because of some specific defect in the interaction of apolipoproteins with the plasma membrane.

In support of this hypothesis are results showing an apparent abnormal binding of apo A-I to Tangier fibroblasts. Using an assay that measures cell-associated apo A-I after sequential washing of cells at $0^{\circ} \mathrm{C}$, we found that apo A-I binds extensively to multiple sites on both normal and Tangier fibroblasts. This may be because lipid-depleted apo A-I is lipophilic and interacts avidly with different lipid domains of the plasma membrane. Most of the cellular interactions of apo A-I measured by our binding assay do not appear to play a role in removing cholesterol and phospholipids, as both normal and Tangier cells progressively bound more apo A-I as its concentration was raised above that needed to saturate cholesterol removal from normal cells $\left(\sim 10^{-7} \mathrm{M}\right)$. At below saturating concentration, however, Tangier cells bound significantly less apo A-I than normal cells, although some binding was still detectable. Reciprocal plots of 
C $4^{\circ} \mathrm{C}$

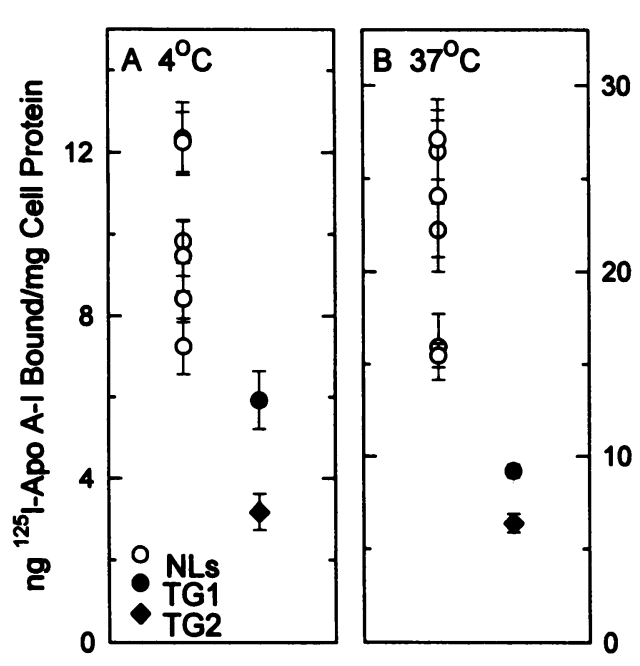

Figure 11. Comparison of highaffinity ${ }^{125} \mathrm{I}$-apo $\mathrm{A}-\mathrm{I}$ binding at $0^{\circ} \mathrm{C}$ and $37^{\circ} \mathrm{C}$ among normal and Tangier fibroblasts. For $A$ and $B$, cholesterol-loaded fibroblasts were incubated with albumin medium containing $0.5 \mu \mathrm{g} / \mathrm{ml}^{125} \mathrm{I}$-apo A-I $\pm 50 \mu \mathrm{g} / \mathrm{ml}$ unlabeled apo A-I for either $3 \mathrm{~h}$ at $0^{\circ} \mathrm{C}(A)$ or $2 \mathrm{~h}$ at $37^{\circ} \mathrm{C}(B)$. Chilled and washed cells were assayed for cell-associated radioactivity as described for Fig. 10 and in Methods. Results are the mean $\pm S D$ of triplicate incubations expressed as the difference between cell-associated radioactivity in the presence and absence of excess unlabeled apo A-I. For $C$, cholesterol-loaded cells were incubated for $3 \mathrm{~h}$ at $0^{\circ} \mathrm{C}$ with medium containing albumin and $1 \mu \mathrm{g} / \mathrm{ml}^{125} \mathrm{I}$-apo A-I, washed extensively, dislodged from the dishes, and pelleted in a microfuge

(see Methods). Cells were solubilized in SDS buffer, and equal amounts ( $50 \mu \mathrm{g}$ ) of cellular protein were applied to each lane of an SDS polyacrylamide gel. After electrophoresis, bands were visualized by autoradiography. The position of ${ }^{125} \mathrm{I}$-apo A-I in the unincubated medium is shown.

the binding curves suggested that this was due to a below normal overall affinity of these binding sites for apo A-I. This reduced high-affinity binding was observed at both $0^{\circ}$ and $37^{\circ} \mathrm{C}$, indicating that it could not be attributed to enhanced endocytosis and degradation of apo A-I, as has been reported for monocytes from Tangier patients (9). Frohlich et al. (21) also reported subnormal binding of HDL to adipocytes isolated from Tangier patient TG2. Although the functional significance of this apparent lower affinity binding of apo A-I to Tangier fibroblasts is unknown, it could possibly reflect an absence or defect in a minor subclass of binding sites that normally act as docking receptors for transporting lipids to apo A-I. Confirmation of this hypothesis will require further characterization of apolipoprotein binding sites on normal and Tangier fibroblasts.

Fibroblast membranes contain a $105-\mathrm{kD}$ protein that binds HDL apolipoproteins and is up-regulated when cells are overloaded with cholesterol $(30,31)$, suggesting that this protein may be the putative lipid transport receptor. A protein with the same properties was cloned from a human dermal fibroblast cDNA library (32). We performed ligand blot and immunoblot analysis of membrane proteins from Tangier fibroblasts and found that the relative abundance and HDL binding activity of this protein appeared to be within the normal range for both of our Tangier cell lines (data not shown). Moreover, we were unable to detect any other HDL binding proteins that could account for the differences in apo A-I binding observed between normal and Tangier cells. This indicates either that HDL binding proteins identified by these assays do not play a role in apo A-I-mediated lipid removal or that they function abnormally in Tangier cells. The availability of these Tangier cell lines will allow for further testing of these possibilities.

Several exchangeable apolipoproteins found in HDL are capable of removing lipids from cultured cells $(26,27,33)$. Moreover, lipid-poor particles containing either apo A-I (34) or apo E (35) have been shown to be the initial acceptors of cholesterol when plasma is added to cultured cells. Recent studies from our laboratory (17) showed that synthetic peptides containing two tandem repeats of the class of amphipathic helices common to these apolipoproteins can mimic apo A-I in its ability to remove cellular cholesterol and phospholipids and to interact with high-affinity binding sites on fibroblasts. It remains to be determined if the defect in lipid removal by apo A-I observed in Tangier cells also applies to other purified apolipoproteins, mimetic peptides, and lipid-poor apolipoprotein particles from plasma.

Studies by Robenek and Schmitz (11) showed that cultured fibroblasts from Tangier patients exhibit morphological abnormalities, including a hyperplasic Golgi complex, which they postulated could be related to impaired lipid trafficking. They also showed that both synthesis and catabolism of phospholipids were accelerated in Tangier fibroblasts compared to normal cells (11). Incorporation of choline into both phosphatidylcholine and sphingomyelin was below normal for the Tangier fibroblasts studied in this report, despite a normal to high content of phospholipid mass, consistent with a slower rate of phospholipid turnover in these Tangier cells. We also found that the rate of cholesterol synthesis was below normal for Tangier fibroblasts and that these cells tended to have a higher than normal content of cholesterol. These results would be expected if Tangier cells are unable to excrete excess membrane cholesterol and phospholipids into the growth medium. Alternatively, a slower lipid turnover may reflect a slower growth rate for Tangier cells, which had a proliferation doubling time at least twice that of normal cells. It is unlikely that this slower growth rate could account for the defect in lipid transport observed for Tangier cells, as slower proliferating cells tend to have enhanced HDLmediated cholesterol efflux compared to faster growing cells $(16,31)$. It is possible, however, that impaired apo A-I-medi- 
ated lipid removal and slower cell proliferation are both secondary consequences of a molecule defect in Tangier cells that perturbs membranes.

Although it is not yet known if the same lipid removal disorder observed in fibroblasts applies to other cell types in vivo, the current findings may provide an explanation for the lipid and clinical abnormalities associated with homozygous Tangier disease (1-4). The severe hypoalphalipoproteinemia in these subjects may be related to an inability of nascent HDL particles to pick up phospholipid and cholesterol from tissues. Lacking sufficient substrate for lysolecithin cholesterol acyltransferase, these particles would not mature into cholesteryl ester-rich $\mathrm{HDL}_{3}$ and $\mathrm{HDL}_{2}$ and would be rapidly cleared from the plasma (13). This lack of maturation would also prevent transfer of tissue-generated cholesterol from HDL to triglyceride-rich lipoproteins and LDL by cholesteryl ester transfer protein (36), which may partially explain the low LDL cholesterol levels observed in Tangier patients. In addition, turnover of plasma LDL may be enhanced because the reverse cholesterol transport pathway would not contribute to repression of hepatic LDL receptors (37).

Cellular cholesterol homeostasis in most tissues would not be affected by a defect in apolipoprotein-mediated cholesterol removal because the cholesterol content of their cells is dependent largely on feedback regulation of the cholesterol biosynthetic and LDL receptor pathways (37). Macrophages, however, can internalize cholesterol-rich lipoproteins by receptor pathways that are not repressed when cells overaccumulate cholesterol (38), making these cells dependent on cholesterol removal mechanisms to prevent massive deposition of sterols. This may explain why Tangier patients accumulate excess sterol in tissues containing macrophages and other scavenger cells. Despite this common tissue cholesterol deposition among Tangier patients, only $\sim 40 \%$ of the known homozygotes have had symptoms of atherosclerosis (4). This may be because of the low plasma LDL levels in these patients, which may protect against atherogenesis. Whether or not an individual with Tangier disease develops atherosclerosis may also depend on their relative susceptibility to inflammatory responses that recruit macrophages into the artery wall.

This study demonstrates a cellular defect in HDL apolipoprotein-mediated removal of cellular lipids associated with hypoalphalipoproteinemia and increased atherosclerosis. This raises the possibility that at least some of the inverse relationship between plasma HDL levels and risk for coronary heart disease observed in the general population may reflect acquired or genetic disorders in transport of cellular lipids to HDL apolipoproteins.

\section{Acknowledgements}

We would like to thank Carolyn Johnson, Rosario Bowen, and Maria Culala for excellent technical support and Pat Burns and Stacey Frank for skilled assistance in preparation of the manuscript.

This study was supported by the Medical Research Council of Canada, The Alberta Heritage Foundation, and National Institutes of Health grants HL-18645, DK02456, and HL-31194.

\section{References}

1. Fredrickson, D. S., P. H. Altrocchi, L. V. Avioli, D. S. Goodman, and H. C. Goodman. 1961. Tangier disease: combined clinical staff conference at the National Institute of Health. Ann. Intern. Med. 55:1016-1031.
2. Fredrickson, D. S. 1964. The inheritance of high density lipoprotein deficiency (Tangier disease). J. Clin. Invest. 43:228-236.

3. Assmann, G., A. von Eckardstein, and H. B. Brewer. 1995. Familial HDL deficiency: Tangier disease. In The Metabolic Basis of Inherited Disease. C. R. Scriver, A. L. Beaudet, W. S. Sly, and D. Valle, editors. 7th ed. McGraw-Hill Book Co., New York. 2053-2072.

4. Serfaty-Lacroshiere, C., F. Civeira, A. Lanzberg, P. Isaia, J. Berg, E. D. Janus, M. P. Smith, Jr., P. H. Pritchard, J. Frohlich, R. S. Lee, et al. 1994 Homozygous Tangier disease and cardiovascular disease. Atherosclerosis. 107:85-98.

5. Brewer, H. B., T. Fairwell, M. S. Meng, L. Kay, and R. Ronan. 1983. Human proapo A-I $\mathrm{I}_{\text {Tangier }}$ : isolation of proapo A-I $\mathrm{I}_{\text {Tangier }}$ and the amino acid sequence of the propeptide. Biochem. Biophys. Res. Commun. 113:934-940.

6. Bojanovski, D., R. E. Gregg, and H. B. Brewer, Jr. 1984. In vitro conversion of proapo A-I $\mathrm{I}_{\text {Tangier }}$ to mature apo A-I $\mathrm{I}_{\text {Tangier }}$. J. Biol. Chem. 259:6049-6051.

7. Law, S. W., and H. B. Brewer, Jr. 1985. Tangier disease: the complete amino acid sequence for proapo A-I. J. Biol. Chem. 260:12810-12814.

8. Bojanovski, D., R. E. Gregg, L. A. Zech, M. S. Meng, C. Bishop, R. Ronan, and H. B. Brewer, Jr. 1987. In vivo metabolism of proapolipoprotein A-I in Tangier disease. J. Clin. Invest. 80:1042-1047.

9. Schmitz, G., G. Assmann, H. Robenek, and B. Brennhausen. 1985. Tangier disease: a disorder of intracellular membrane traffic. Proc. Natl. Acad. Sci. USA. 82:6305-6309.

10. Schmitz, G., H. Fischer, M. Beuck, K.-P. Hoecher, and H. Robenek. 1990. Dysregulation of lipid metabolism in Tangier monocyte-derived macrophages. Arteriosclerosis. 10:1010-1019.

11. Robenek, H., and G. Schmitz. 1991. Abnormal processing of Golgi elements and lysosomes in Tangier disease. Arterioscles. Thromb. 11:1007-1020.

12. Walter, M., U. Gerdes, U. Seedorf, and G. Assman. 1994. The high density lipoprotein apolipoprotein A-I-induced mobilization of cellular cholesterol is impaired in fibroblasts from Tangier disease subjects. Biochem. Biophys. Res. Commun. 205:850-856.

13. Horowitz, B. S., J. J. Goldberg, J. Merab, T. M. Vanni, R. Ramakrishnan, and H. N. Ginsberg. 1993. Increased plasma and renal clearance of an exchangeable pool of apolipoprotein A-I in subjects with low levels of high density lipoprotein cholesterol. J. Clin. Invest. 91:1743-1752.

14. Aviram, M., E. L. Bierman, and J. F. Oram. 1989. High density lipoprotein stimulates sterol translocation between intracellular and plasma membrane pools in human monocyte-derived macrophages. J. Lipid Res. 30:65-76.

15. Mendez, A. J., J. F. Oram, and E. L. Bierman. 1991. Protein kinase C as a mediator of high density lipoprotein receptor-dependent efflux of intracellular cholesterol. J. Biol. Chem. 266:10104-10111.

16. Oram, J. F., A. J. Mendez, J. P. Slotte, and T. F. Johnson. 1991. High density lipoprotein apolipoproteins mediate removal of sterol from intracellular pools but not from plasma membranes of cholesterol-loaded fibroblasts. Arterioscler. Thromb. 11:403-414.

17. Mendez, A. J., G. M. Anantharamaiah, J. P. Segrest, and J. F. Oram. 1994. Synthetic amphipathic helical peptides that mimic apolipoprotein A-I in clearing cellular cholesterol. J. Clin. Invest. 94:1698-1705.

18. Bilheimer, D. W., S. Eisenberg, and R. I. Levy. 1972. The metabolism of very low density lipoprotein proteins. Biochim. Biophys. Acta. 260:212-221.

19. Oram, J. F. 1986. Receptor-mediated transport of cholesterol between cultured cells and high density lipoproteins. Methods Enzymol. 129:645-659.

20. Cheung, M. C., A. J. Mendez, A. C. Wolf, and R. H. Knopp. 1993. Characterization of apolipoprotein A-I- and A-II-containing lipoproteins in a new case of high density lipoprotein deficiency resembling Tangier disease and their effects on intracellular cholesterol efflux. J. Clin. Invest. 91:522-529.

21. Frohlich, J., B. Fong, P. Julien, J.-P. Despres, A. Angel, M. Hayden, R. McLeod, C. Chow, R. H. Davison, and H. Pritchard. 1987. Interaction of high density lipoprotein with adipocytes in a new patient with Tangier disease. Clin. Invest. Med. 10:337-382.

22. Folch, J., M. Lees, and G. H. Sloane-Stanley. 1957. A simple method for the isolation and purification of total lipids from animal tissues. J. Biol. Chem. 226:497-509.

23. Hess, H. H., and J. E. Derr. 1975. Assay of inorganic and organic phosphorus in the 0.1-5 nanomole range. Anal. Biochem. 63:607-613.

24. Laemmli, U. K. 1970. Cleavage of structural proteins during the assembly of the head of bacteriophage T4. Nature (Lond.). 227:680-686.

25. Rothblat, G. H., and M. C. Phillips. 1991. Cholesterol efflux from arterial wall cells. Curr. Opin. Lipidol. 2:288-294.

26. Hara, H., and S. Yokoyama. 1991. Interaction of free apolipoproteins with macrophages. J. Biol. Chem. 266:3080-3086.

27. Hara, H., and S. Yokoyama. 1992. Role of apolipoproteins in cholesterol efflux from macrophages to lipid microemulsion: proposal of a putative model for the pre- $\beta$ high density lipoprotein pathway. Biochemistry. 31:2040-2046.

28. Bielicki, J. K., W. J. Johnson, R. B. Weinberg, J. M. Glick, and G. H. Rothblat. 1992. Efflux of lipid from fibroblasts to apolipoproteins: dependence 
on elevated levels of cellular unesterified cholesterol. J. Lipid Res. 33:1699_ 1709.

29. Forte, T. M., R. Goth-Goldstein, R. W. Nordhausen, and M. R. McCall. 1993. Apolipoprotein A-I cell membrane interaction: extracellular assembly of heterogeneous nascent HDL particles. J. Lipid Res. 34:317-324.

30. Graham, D. L., and J. F. Oram. 1987. Identification and characterization of a high density lipoprotein-binding protein in cell membrane by ligand blotting J. Biol. Chem. 262:7439-7442.

31. Oppenheimer, M. J., J. F. Oram, and E. L. Bierman. 1988. Up-regulation of high density lipoprotein receptor activity by gamma-interferon associated with inhibition of cell proliferation. J. Biol. Chem. 263:19318-19323.

32. McKnight, G. L., J. Reasoner, T. Gilbert, K. O. Sundquist, B. M. Hokland, P. A. McKernan, J. Champagne, C. J. Johnson, M. C. Bailey, R. Holly, et al. 1992. Cloning and expression of a cellular high density lipoprotein-binding protein that is up-regulated by cholesterol loading of cells. J. Biol. Chem. 267:1213112141.
33. Hara, H. H., M. Hiroko, A. Komaba, and S. Yokoyama. 1992. $\alpha$-helical requirements for free apolipoproteins to generate HDL and to induce cellular lipid efflux. Lipids. 27:302-304.

34. Castro, G. R., and C. J. Fielding. 1988. Early incorporation of cell-derived cholesterol into pre-beta-migrating HDL. Biochemistry. 27:25-29.

35. Huang, Y. A. Eckardstein, S. Wu, N. Maeda, and G. Assmann. 1994. A plasma lipoprotein containing only apolipoprotein $\mathrm{E}$ and with gamma mobility on electrophoresis releases cholesterol from cells. Proc. Natl. Acad. Sci. USA 91:1834-1838.

36. Tall, A. R. 1993. Plasma cholesteryl ester transfer protein. J. Lipid Res. 34:1255-1274.

37. Brown, M. S., and J. L. Goldstein. 1986. A receptor-mediated pathway for cholesterol homeostasis. Science (Wash. DC). 232:34-47.

38. Brown, M. S., and J. L. Goldstein. 1983. Lipoprotein metabolism in the macrophage: implications for cholesterol deposition in atherosclerosis. Annu. Rev. Biochem. 52:223-261. 